DOI

\title{
НА ДОПОМОГУ СІМЕЙНОМУ ЛІКАРЮ: ДІАГНОСТИКА ТА ЛІКУВАННЯ КОН'ЮНКТИВІТІВ У ДІТЕЙ І ДОРОСЛИХ В УМОВАХ ПОЛІКЛІНІКИ
}

\author{
๑В. Д. Міхель, М. А. Діогенова, Ю. В. Божович, Н. М. Кіндзерська \\ Львівський національний медичний університет імені Данила Галицького
}

РЕЗЮМЕ. У статті наведено результати досліджень ефективності лікування синдрому сухого ока, вірусних, алергічних і бактерійних кон'юнктивітів очними краплями Окуфлеш у 716 пацієнтів різних вікових категорій, серед яких були 24 вагітні жінки і 187 дітей (0-14 років). Препарат застосовували як у вигляді монотерапії, так і в складі комплексного лікування. Окуфлеш закрапували 5 разів на день по 1-2 краплі до кон'юнктивального мішка протягом 2 днів і більше до моменту одужання (в середньому 5-9 днів). Отримані результати підтвердили, що Окуфлеш не викликає місцевого і системного побічних ефектів у дорослих, вагітних жінок, дітей, у тому числі від 0 до 1 року, а також у пацієнтів з обтяженим алергічним анамнезом. Очні краплі Окуфлеш сприяють швидшому зникненню симптомів і скороченню термінів лікування всіх кон'юнктивітів, знімають симптоми втоми очей і відчуття дискомфорту, можуть застосовуватися тривало для профілактики та гігієни кон'юнктивального мішка. Пацієнти, особливо вагітні жінки і матері хворих дітей, охочіше і без остраху застосовують очні краплі рослинного походження, ніж краплі з антибіотиками.

КЛЮЧОВІ СЛОВА: кон'юнктивіт, антисептик рослинного походження, Euphrasia officinalis, Окуфлеш, бактерійний кон'юнктивіт, вірусний кон'юнктивіт, алергічний кон'юнктивіт, синдром сухого ока, лікування.

Вступ. В умовах поліклінічного прийому сімейному лікарю щодня трапляються пацієнти із загальними симптомами вірусно-бактерійних інфекцій, які проявляються як з боку верхніх дихальних шляхів, так і з боку очей. Серед різноманітних запалень переднього відтинку ока кон'юнктивіти бактеріального, вірусного та алергічного характеру становлять від 50 до 90 \% усіх запальних захворювань ока.

Сімейний лікар - це перша ланка медичної допомоги населенню, тому він повинен вчасно та вірно діагностувати захворювання, призначити адекватне лікування і спостерігати пацієнта від початку і до кінця лікування.

Основними діагностичними критеріями кон'юнктивітів $\epsilon$ почервоніння кон'юнктиви очного яблука і виділення з кон'юнктивального мішка (водянисті при алергічних, вірусних і сухих, слизово-гнійні або гнійні - при бактерійних захворюваннях). Окрім того, часто кон'юнктивіти супроводжуються світлобоязню і сльозотечею, відчуттям стороннього тіла або піску в очах.

За останні 30-40 років збільшилися ріст резистентних штамів збудників до більшості антибіотиків (до $70 \%$ ) і полірезистентність до комбінованих антибіотиків, які застосовуються одночасно.

Несвоєчасне або невірне діагностування власне кон'юнктивіту і неправильно призначене лікування призводить до виникнення значної кількості хронічних і алергічних захворювань ока, що ускладнює і подовжує лікування пацієнта.

Часто необґрунтоване і тривале призначення антибіотиків призводить до алергізації, викликає токсичну дію, побічні явища і ускладнення. У та- ких випадках антисептики стають основним методом лікування кон'юнктивітів.

Лікування кон'юнктивітів, крім етіотропного і патогенетичного, має включати ад'ювантну терапію, а саме промивання кон'юнктивального мішка антисептиками, у тому числі настоями лікарських трав.

Наш досвід успішного лікування кон'юнктивітів показав, що застосування антисептичного препарату Окуфлеш у вигляді очних крапель дає позитивні результати вже на 2-3 день від початку лікування.

Окуфлеш привернув нашу увагу тому, що він виготовлений на основі екстракту очанки лікарської (Euphrasia officinalis). Здавна відомі її протизапальна, імуномоделююча, антисептична, бактеріостатична, відхаркувальна, в'яжуча, заспокійлива, знеболювальна, протисудомна, гіпотензивна, протиалергічна, протинабрякова, спазмолітична, обволікувальна, антикатарактальна дії. Ця рослина містить аукубін та інші іридоїдні глікозиди, лігнан, флавоноїди, кумарини, сапоніни, антоціани, дубильні речовини (галотаніни), горючі, ефірні та жирні олії, смоли, синій фарбник, вітаміни А, С, групи В, мікроелементи (кремній, залізо, марганець, мідь, магній, цинк, нікель, срібло, хром, молібден і бор). Очанка (еуфразія) з 2001 року входить до Європейської Фармакопеї.

Мета - дослідити ефективність лікування кон'юнктивітів препаратом Окуфлеш у дітей і дорослих в умовах поліклініки.

Матеріал і методи дослідження. У період з вересня 2011 року по квітень 2016 року нами було застосовано Окуфлеш у лікуванні інфекцій- 
Огляди літератури, оригінальні дослідження, погляд на проблему

них і неінфекційних кон'юнктивітів у 716 чоловік, серед яких були 24 вагітних жінки і 187 дітей.

Дорослих пацієнтів (529 чоловік) віком 1968 років ми спостерігали у обласній консультативній поліклініці Львівської обласної клінічної лікарні i районних поліклініках Яворівського i Кам'янко-Буського району Львівської області (смт. Новий Яричів), дітей віком від двох тижнів до 14 років -у цих же райполіклініках.

Серед дорослих нами була діагностована така патологія: синдром сухого ока - 167 чоловік, алергічний кон'юнктивіт - 105 чоловік, вірусний кон'юнктивіт - 141 чоловік, бактерійний - 116 чоловік. П'ять пацієнтів мали в анамнезі алергію майже на всі місцеві та загальні медикаменти.

У дітей нозологічна картина була такою: синдром сухого ока - 8 чоловік, алергічний кон'юнктивіт - 43 чоловіки, вірусний кон'юнктивіт - 57 чоловік, бактерійний кон'юнктивіт - 79 чоловік.

У більшості випадків (75\%, 537 осіб) Окуфлеш застосовували у дорослих і дітей у вигляді монотерапії: 5 разів на день по 1-2 краплі до кон'юнктивального мішка впродовж 2 днів і більше до моменту одужання.

У решті випадків Окуфлеш призначали у складі комплексної терапії.

Результати й обговорення. Усі пацієнти 3 1-2 дня використання препарату Окуфлеш відмічали зменшення дискомфорту в очах і виділень,

\section{ЛІТЕРАТУРА}

1. Землинский С. Е. Лекарственные растения CССР: третье издание, исправленное и дополненное / С. Е. Землинский. - М. : Метгиз, 1958.

2. Адигезалова-Полчаева К. А. Влияние некоторых препаратов растительных антибиотиков на аденовирусы / К. А. Адигезалова-Полчаева, Ш. Р. Сафарли, А. Г. Сулейманов // Материалы II конф. офтальмологов Закавказья. - Ереван, 1971. - С. 364-366.

3. Бунин А. Я. Офтальмофармакология и фармакотерапия глазных заболеваний - достижения и перспективы / А. Я. Бунин, Ю. Ф. Майчук // Вестн. офтальмологии. - 1977. - № 5. - С. 73-79.

4. Чекман И. С. Осложнения фармакотерапии / И. С. Чекман. - К. : Здоров'я, 1980. - 236 с.

5. Горгиладзе Т. У. Лечение некоторых острах поражений роговицы / Т. У. Горгиладзе // Междунар. конф. офтальмологов городов-побратимов Одессы : Тез. докл. - Одесса, 1981. - С. 18-19.

6. Майчук Ю. Ф. Аллергические заболевания глаз / Ю. Ф. Майчук. - М. : Медицина, 1983. - 224 с.

7. Горгиладзе Т. У. Кератопластика при воспалительных заболеваниях роговицы / Т. У. Горгиладзе // Офтальмол. журн. - 1983. - № 2. - С. 71-75.

8. Каспаров А. А. Инфекционные воспалительные заболевания наружного отдела глаза / А. А. Каспаров // Вестн. Офтальмологии. - 1987. - № 1. - С. 61-62. сльозотечі, світлобоязні та почервоніння. У дітей і вагітних жінок спостерігали швидке зникнення симптомів захворювання.

На 5-7 день у 89 \% пацієнтів зникли всі скарги і клінічні прояви захворювання, але ми продовжували закапувати Окуфлеш ще 3-5 днів.

Усі пацієнти були задоволені безпечністю лікування очними краплями на рослинній основі.

Висновки. Окуфлеш добре переносять дорослі, вагітні жінки, діти (у тому числі від 0 до 1 року), а також пацієнти з обтяженим алергічним анамнезом.

Препарат не викликає місцевого і системного побічних ефектів. Пацієнти, особливо вагітні жінки і мами хворих дітей, охочіше і без остраху застосовують очні краплі рослинного походження, ніж краплі з антибіотиками.

Очні краплі Окуфлеш сприяють більш швидкому зникненню симптомів і скороченню термінів лікування всіх кон'юнктивітів, знімають симптоми втоми очей і відчуття дискомфорту, можуть застосовуватися тривало для профілактики та гігієни кон'юнктивального мішка.

Перспективи подальших досліджень. Ефективність та безпечність препарату «Окуфлеш» при лікуванні кон'юнктивітів у пацієнтів різного віку зумовлює необхідність подальшого вивчення його лікувальної дії в дитячій офтальмології із застосуванням доказової медицини.

9. Можеренков В. П. Медикаментозные поражения роговицы : обзор / В. П. Можеренков, Г. Л. Прокофьева // Мед. реф. журн. - 1988. - Разд.VIII, № 1. -С. 9-11.

10. Лікарські рослини: енциклопедичний довідник ; відп. ред. А. М. Гродзінський. - К. : Голов. Ред. УРЕ, 1991. - 317 c.

11. Можеренков В. П. Медикаментозные поражения органа зрения (обзор) / В. П. Можеренков, Г. Л. Прокофьева // Вестн.офтальмологии. - 1992. - № 1. C. 46-48.

12. Майчук Ю. Ф. Терапия инфекционных заболеваний глаз / Ю. Ф. Майчук // Офтальмологический журнал. - 1996. - № 4. - С. 193-199.

13. Эффективность препарата «Окуфлеш» при заболеваниях переднего отдела глаза у детей и взрослых / В. Д. Михель, Ю. В. Божович, М. А. Диогенова, Н. Е. Чемеринска // Укр. мед. часопис. - 2013. - № 1 (93). C. $120-121$.

14. Олейник О. М. Новое в лечении заболеваний переднего отдела глаза у недоношенных детей первого года жизни / О. М. Олейник, З. В. Салабай, С. В. Процык // Восточная Европа. - № 3 (07). - 2014. - С. 125-130.

15. British Herbal Pharmacopoeia. The British Herbal Medicine Association. Keighley: Yorks, U.K. - 1983.

16. Stoss M. Prospective of Cohort Trial of Euphrasia single-dose Eye Drops in Conjunctivitis / Stoss M. // The 
Огляди літератури, оригінальні дослідження, погляд на проблему

Journal of Alternative and Complementary Medicine. 2000. - Vol. 6, № 6. - P. 499-508.

17. Bielory L. Review of complementary and alternative medicine in treatment of ocular allergie / L. Bielory, J. Heimall // Current opinion in Allergy and Clinical immu- nology. - 2003. - № 3 (5). - P. 395-399

18. Draft assessment report on Euphrasia officinalis L. and Euphrasia rostkoviana Hayne, herba, (Committee on Herbal Medicinal Products, London, 12 November 2009). European Medicines Agency. - London. - 2010.

\title{
TO HELP FAMILY DOCTOR: DIAGNOSIS AND TREATMENT OF CONJUNCTIVITIS IN ADULTS AND CHILDREN IN A POLYCLINIC PRACTICE
}

\author{
OV. D. Mikhel, M. A. Diohenova, Yu. V. Bozhovych, N. M. Kindzerska \\ Danylo Halytsky Lviv National Medical University
}

\begin{abstract}
SUMMARY. The article provides the results of treatment with eye drops "Okuflesh" of dry eye syndrome, viral, allergic, and bacterial conjunctivitis in 716 patients of various ages, including 24 pregnant women and 187 children (0-14 years old). The drug was used as a monotherapy and as a part of a comprehensive treatment. "Okuflesh" was instillated for 1-2 drops to the conjunctival cavity 5 times per day for 2 days or more until the recovery (in average 5-9 days). The results assume that "Okuflesh" does not cause local and systemic side effects in adults, pregnant women and children, including from 0 to 1 year old, and in patients with complicated allergic history. The eye drops "Okuflesh" contributes to more rapid disappearance of symptoms and to the reducing the treatment process of conjunctivitis, relieves symptoms of eye fatigue and discomfort, can be applied for continued prevention and for the hygiene of the conjunctival cavity. Patients, especially pregnant women and mothers of ill children, are more likely to safely choose eye drops of vegetable origin than drops with antibiotics.

KEY WORDS: conjunctivitis, herbal antiseptic, Euphrasia officinalis, Okuflesh, bacterial conjunctivitis, viral conjunctivitis, allergic conjunctivitis, dry eye syndrome, treatment.
\end{abstract}

